\title{
Numerical Taxonomy of the Asclepiadaceae s.l.
}

\author{
Adel El-Gazzar ${ }^{(1) \#}$, Adel H. Khattab ${ }^{(2)}$, Albaraa El-Saeid ${ }^{(3)}$, Alaa A. El-Kady ${ }^{(3)}$ \\ (1)Departmentof Botany \& Microbiology, Faculty of Science, El-Arish University, \\ Norht Sinai, Egypt; (2) The Herbarium, Botany Department, Faculty of Science, Cairo \\ University, Giza, Cario, Egypt and ${ }^{(3)}$ Department of Botany \& Microbiology, Faculty \\ of Science, Al-Azhar University, Cairo, Egypt.
}

\begin{abstract}
$\mathbf{A}^{\mathrm{s}}$ SET of 58 characters was recorded comparatively for a sample of 76 species belonging to 31 genera of the Asclepiadaceae R.Br. The characters cover variation among the species in gross vegetative morphology, floral features and structure of the pollination apparatus. The data-matrix was analyzed using a combination of the Jaccard measure of dissimilarity and Ward's method of clustering in the PC-ORD version 5. Two major groups are recognized in this treatment, the first comprises representative genera of the Asclepiadoideae, while the second is split into two subordinate groups corresponding to the Periplocoideae and the Secamonoideae. Tacazzia seems better removed from the Periplocoideae and placed in the Asclepiadoideae. The generic concept in the family is taxonomically sound; only representative species of Cynanchum were divided between two closely related low-level groups. The currently accepted tribes and subtribes in Schumann's classification are in need of thorough revision; only the Secamonoideae-Secamoneae emerged intact.
\end{abstract}

Keywords: Asclepiadaceae s.l., Classification, Cluster analysis, Morphology, Pollen tetrads, Pollinia.

\section{Introduction}

The Asclepiadaceae R.Br. ( ApocynaceaeAsclepiadoideae Burnett) are a relatively large family of angiosperms comprising some 348 genera and about 2900 species (APG IV, 2016), distributed mainly in the tropical and subtropical regions of the world. The plants are annual or perennial herbs, climbers, scramblers, or xerophytic succulents with copious milky latex. The leaves are invariably simple, opposite decussate, exstipulate, sometimes reduced or transformed into spines. The stem is cylindrical in the mesophytes and semi-succulents, and angled in the succulent taxa. Flowers are hermaphrodite, actinomorphic, sympetalous, hypogynous and with pentamerous (rarely teramerous) whorls which possess a remarkably wide range of variation in shape and size. Calyx of 5 united imbricate sepals; corolla of 5 united petals, the tube varies greatly in length, lobes imbricate; corona arising as outgrowth of petals or bases of staminal filaments; androecium of 5 free stamens, anther lobes adhere to stigma; carpels 2, ovaries free, styles 2 but fuse together shortly below the capitate stigma; fruit of 2 dehiscent follicles with numerous seeds on a parietal placenta; seeds usually with a distal tuft of silky hairs (Watson \& Dallwitz, 1992 onwards).
Perhaps the most striking feature of the Asclepiadaceae R.Br. is the complexity of pollen aggregation within anther lobes and the mechanism of their release upon anthesis. Anthers are invariably two-lobed and each anther lobe contains a number of separate tetrads of different configurations, or one, two or four pollen masses (pollinia) exhibiting a wide range of shapes and sizes (El-Gazzar \& Hamza, 1973; El-Gazzar et al., 1974; Schill \& Jäkel, 1978 and Sreenath et al., 2012); none of the species has as yet been reported to have pollen monads. The free pollinia of ten Asian genera of the Periplocoideae and the separate tetrads in the rest of the subfamily are shed on a translator consisting of a spoon, stalk and an adhesive disc (Verhoeven \& Venter, 1998). In contrast, the pollinia of adjacent anthers in the rest of the Asclepiadaceae s.l. are attached to each other through a pair of caudicles which are in turn attached to a corpuscle at one of the four or five corners of the stigma. Furthermore, in members of the Asclepiadoideae each pollinium is enveloped by a thin common membrane, whereas in the ten Asian genera of the Periplocoideae with pollinia (Verhoeven \& Venter, 1998) and in the Secamonoideae (Endress \& Bruyns, 2000), this common membrane is lacking. Thus, in species with pollinia, the flower contains five pollinial

\#Corresponding author email: elgazzar_adel@hotmail.com

DOI: 10.21608/ejbo.2018.3035.1156

Edited by: Prof. Dr. Adel Elgazzar, Faculty of Science, Suez Canal University, El-Arish, N. Sinai, Egypt.

C2018 National Information and Documentation Center (NIDOC) 
apparatus each consisting of one or two pairs of pollinia (each from a different anther), a pair of caudicles and a common corpuscle. Caudicles and corpuscles are either pale and soft (in the Secamonoideae) or dark and horny in the Asclepiadoideae (El-Gazzar \& Hamza, 1973; El-Gazzar et al., 1974 and Verhoeven \& Venter, 1998).

The circumscription, subdivision and disposition of the Asclepiadaceae were for more than two centuries a matter of taxonomic controversy. As early as 1789 , Antoine Laurent de Jussieu established "order" Apocineae to include the following three groups of genera:

(a) Ovaries two, fruit of two follicles, seeds without pappus: Vinca, Matelea, Ochrosia, Tabernaemontana, Cameraria, Plumeria.

(b) Ovaries two, fruit 2-loculed, seeds with pappus: Nerium, Echites, Ceropegia, Pergularia, Stapelia, Periploca, Apocinum, Cynanchum, Asclepias.

(c) Ovary single, fruit drupe (rarely capsule): Ambelania, Pacouria, Allamanda, Melodinus, Gynopogon, Rauvolfia, Ophioxylon, Cerbera, Carissa.

During the next two decades, the number of new genera increased dramatically so that this tentative arrangement became insufficient for accommodating them and a new classification was established by Robert Brown (1811), who separated Matelea from group (a) together with the genera of group (b) (except Nerium) into the new "order" Asclepiadeae. Brown also shifted the emphasis from gynoecium morphology to the newly discovered variation in the structure of the pollination apparatus thus leading to the establishment of the following classification [diagnoses are translated from the original version in Latin]:

I. Asclepiadeae Verae: Pollen masses 10, smooth, in pairs (each belonging to a different anther), attached to the stigma through a longitudinally sulcate corpuscle of the stigma. Filaments connate, often with outer appendages: Ceropegia, Huernia, Piaranthus, Stapelia, Caralluma, Microstemma, Leptadenia, Hoya, Tylophora, Marsdenia, Pergularia, Dischidia, Gymnena,
Sarcolobus, Gonolobus, Matelea, Asclepias, Gomphocarpus, Oxystelma, Xysmalobium, Calotropis, Oxypetalum, Kanahia, Diplolepis, Holostemma, Cynanchum, Metaplexis, Ditassa, Daemia, Sarcostemma, Eustegia (31 genera).

II. [Unnamed]: Pollen masses 20, smooth, in tetrads (each pair belonging to a different anther), apex attached directly to corpuscle of the stigma. Filaments connate, appendiculate on the outside: Secamone (one genus).

III. Periploceae: Pollen masses 5-20, granulose (a granule consists of 4 spheres), solitary. Filaments partly or completely free: Hemidiscus, Periploca, Gymnanthera (3 genera).

Brown's (1811) classification was subjected to various enlargements and modifications by subsequent authors. Decaisne (1844) recognized no subfamilies but divided the family directly into 5 tribes of equal ranking. Bentham \& Hooker (1876), on the other hand, classified the genera into two "sub-orders": The Periploceae and the Euasclepiadeae, with the latter group being divided into seven tribes (including the Secamoneae). The most comprehensive and immaculately illustrated account of the Asclepiadaceae R.Br. was provided by Schumann (1895), who accepted Bentham and Hooker's subdivision of the family into two subfamilies (Periplocoideae and Cynanchoideae) but divided the latter into only five tribes (including the Secamoneae). Clearly, in all of these traditional classifications, Brown's (1811) separation of the Asclepiadaceae from the Apocynaceae was accepted. In a brief note, Schlechter (1905) was the first to elevate the Periploceae (or Periplocoideae sensu Schumann) to the rank of family (the Periplocaceae), because they differed from the rest of Schumann's Asclepiadaceae sensu lato in having tetrads of pollen grains instead of pollen masses (pollinia), the lack of caudicles and corpuscles, and in corolla structure. Later, Schlechter (1924) re-iterated in more detail the distinctness of the Periplocaceae. In doing so, Schlechter left only Schumann's (1895) Cynanchoideae within the boundaries of the Asclepiadaceae sensu stricto, but his views were accepted by some subsequent authors, e.g., Dave \& Kuriachen (1991); Nilsson et al. (1993) and Kunze (1996) and refused by others who recognized three subfamilies (Asclepiadoideae, 
Periplocoideae and Secamonoideae) in the family, e.g., Liede \& Albers (1994), Swarupanandan et al. (1996), Verhoeven \& Venter (1998) and Meve \& Liede-Schumann (2004).

The Asclepiadaceae s.l. (i.e. including the Periplocoideae) were first reduced to the rank of subfamily (Asclepiadoideae) within an expanded concept of the Apocynaceae by Sennblad \& Bremer (1996) on the basis of sequencing data of the $r b c \mathrm{~L}$ gene in 17 and seven species of the Apocynaceae and Asclepiadaceae, respectively. This drastic change in the status of asclepiads persisted in subsequent studies dealing with members of this group at all hierarchical levels (Endress \& Bruyns, 2000; Endress, 2001; Sennblad \& Bremer, 2002; Livshultz et al., 2007; Soares e Silva et al., 2012; Meve \& LiedeShumann, 2012; Liede-Shumann et al., 2012 and 2014; Endress et al., 2014; Surveswaram et al., 2014; Khanum et al., 2016; APG IV, 2016 and Meve et al., 2017). Even with this wide acceptance of treating Shumann's (1895) Asclepiadaceae as a subfamily of the Apocynaceae s.l., the main infrafamilial taxa of the asclepiads remained almost unaltered for more than 120 years, apart from the necessary nomenclatural adjustments.

Recognition of sub-families, tribes and subtribes in Schumann's (1895) classification of the Asclepiadaceae was based almost entirely on characters of the pollinial apparatus and the mechanism of pollen release, thus overlooking most of the much wider range of morphological variation in the vegetative and floral parts of the plants. As a contribution from floral and vegetative morphology to the taxonomy of the Asclepiadaceae s.l., the present study was undertaken to subject variation in the largest possible number of characters recorded comparatively from a cosmopolitan representative sample of the genera and species to numerical analysis and comparing the result with the currently accepted groupings in Schumann's classification (1895).

\section{Materials and Methods}

Herbarium specimens of a cosmopolitan sample of 76 species representing 31 genera of the Ascepiadaceae s.l. were obtained on loan from the herbarium of the Botany Department, Faculty of Science, Cairo University (CAI; acronym according to Holmgren et al., 1990). This sample was supplemented with fresh material of some taxa collected locally and kept in the herbarium of the Botany and Microbiology Department, Faculty of Science in Cairo, Al-Azhar University. The 31 genera (with the number of subordinate taxa from each genus in parentheses) are: Araujia (1), Asclepias (7), Blyttia (1), Calotropis (1), Caralluma (3), Cryptostegia (1), Cryptolepis (1), Cynanchum (6), Dregea (2), Genianthus (2), Glossonema (3), Gomphocarpus (2), Gymnema (1), Hoya (1), Huernia (1), Kanahia (1), Leptadenia (3), Marsdenia (1), Oxystelma (2), Pachycarpus (1), Pentarrhinum (1), Pergularia (2), Periploca (6), Pervillaea (1), Pleurostelma (1), Secamone (13), Solenostemma (2), Streptocaulon (1), Tacazzea (1), Toxocarpus (5), and Vincetoxicum (2).

The number of specimens representing each species ranged between one (e.g. for Araujia sericifera Brot., Dregea schimperi (Decne.) Bullock, Oxystelma bornouense R.Br.) and 29 (for Calotropis procera (Aiton) Aiton); see Appendix. Identity of taxa was confirmed using appropriate local floras and nomenclature of the species was updated according to the two websites (http://www.theplantlist.org/), and (http://www. tropicos.org), where full lists of synonyms and author citations can be found. Full names of taxa with author citations, abbreviations used in the numerical analysis and collection data of the specimens examined are given in the Appendix.

As many aspects of variation in vegetative and floral morphology as can be found in the available specimens were recorded comparatively in a data matrix. Parts of leaves were cleared to score the presence or absence of glandular hairs and the two forms of calcium oxalate crystals (druses and prismatics). Mature flowers were resuscitated and dissected on a slide torecord morphological variation in their parts. Semi-permanent pollen preparations were made according to the method of Franks \& Watson (1963).

The data matrix was subjected to analysis under the combination of the Jaccard distance measure and Ward's clustering method; both are available in the program packagePC-ord version 5 for Windows (McCune, 1997).

\section{Results}

A total of 58 characters were recorded for each of the 76 species representing 31 genera of 
the Asclepiadaceae s.l. (Table 1). They cover a wide range of variation in the gross morphology of the floral and vegetative parts of the plants, including their general aspects, growth forms, inflorescence type, as well a few microscopic characters (glandular hairs and calcium oxalate crystals in leaf mesophyll). Morphological variation in sepals, petals, corona, staminal filaments, ovaries, styles, stigmas, gynophores and nectar discs was also entered into the data matrix. The pollinial apparatus (tetrads, pollinia, caudicles and corpuscles) contributed richly to the data matrix. The list of characters in Table 1 includes 49 qualitative characters and nine multistate characters (number 5, 8, 12, 13, 32, 37, $40,44,55)$.

TABLE1. List of 58 morphological and palynological characters recorded comparatively for the 76 taxa belonging to 31 genera of the Asclepiadaceae s.l. and subjected to numerical analysis.

1. Plant

2. Stem

3. Stem

4. Stem

5. Stem

6. Stem

7. Stipules

8. Leaves

9. Leaves

10. Prismatic crystals

11. Druses

12. Leaf arrangement

13. Leaves

14. Leaf-blade

15. Glandular hairs on leaves

16. Midrib and veins

17. Base of leaf blade

18. Leaf margin

19. Leaf margin

20. Leaf apex

21. Inflorescence

22. Flower

23. Calyx lobes

24. Sepal apex

25. Sepal outer surface

26. Petal apex

27. Corona

28. Corona colour

29. Corona

30. Corona

31. Corona

32. Staminal filaments

33. Caudicles

34. Caudicles

35. Caudicle attachment to pollinia:

36. Pollen aggregation

37. Number of pollinia/anther lobe:

38. Pollinia

39. Pollinium thin envelop

40. Pollinium wall

41. Germination
Herb 1/shrub 0

Succulent $1 /$ not succulent 0

Hairy $1 /$ glabrous 0

Cylindrical 1/angled 0

Erect 1/climbing-twining 2/procumbent 3

Articulated $1 /$ continuous 0

Present 1/absent 0

Petioled 1/sessile-subsessile 2/reduced 3

Fleshy $1 /$ not fleshy 0

Present $1 /$ absent 0

Present $1 /$ absent 0

Alternate 1/opposite 2/whorled 3

Ovate-elliptic 1/oblong 2/ linear-lanceolate 3/cordate 4/reduced 5

Hairy 1 /glabrous 0

Present 1 /absent 0

Hairy 1 /glabrous 0

Cordate $1 /$ not cordate 0

Entire and pellucid 1/undulate 0

Hairy $1 /$ smooth 0

Acute 1/obtuse 0

Solitary $1 /$ umbel 0

Spedicelled 1/sessile-subsessile 0

As long as corolla tube or shorter $1 /$ much longer 0

Acute 1/obtuse 0

Hairy 1 /glabrous 0

Acute 1/obtuse 0

5 free translators $1 /$ tubular 0

Same as petal lobes $1 /$ different 0

Single 1/double 0

Attached to corolla 1/attached to staminal column 0

Toothed $1 /$ toothless 0

Hairy $1 /$ glabrous $2 /$ reduced 3

Long1/inconspicuous 0

Stiff $1 /$ pale and soft 0

a: Terminal 1 /subterminal-median0

Tetrads 1 (Fig. 1)/pollinia 0 (Fig. 2-4)

One $1 /$ two $2 /$ four 3

Pendulous 1 (Fig. 2)/erect-horizontal0 (Fig. 3-4)

Present 1 /absent 0

Filled completely with pollen grains $1 /$ distal part empty $2 /$ outer lateral part empty $3 /$ inner lateral part empty 4

Through pore $1 /$ longitudinal slit 0 
42. Styles

43. Styles

44. Stigma

45. Corpuscles

46. Corpuscles

47. Corpuscles

48. Corpuscle apex

49. Ovaries

50. Ovaries

51. Ovaries

52. Nectar disc

53. Gynophore

54. Fruit

55. Fruit surface

56. fruit apex

57. Seeds

58. Tuft of hairs on seed
Filiform 1/slender-reduced 0

United $1 /$ free 0

Cylindrical 1/globose 2/ two-lobed 3/ tetragonal 4/ pentagonal 5

Present 1/absent 0

Dark and horny 1 (Fig. 2)/pale and soft 0 (Fig. 3-4)

Sulcate $1 /$ not sulcate 0

Bifid 1 (Fig. 3-4)/not bifid 0

Hairy 1 /glabrous 0

On top of nectar disc $1 /$ sunken in nectar disk 0

United $1 /$ free 0

Present $1 /$ absent 0

Present $1 /$ absent 0

Two divaricate follicles 1 /indehiscent mericarps 0

Smooth 1 /warty 2 /spiny 3

Hooked 1/not hooked 0

Flattened 1 /discoid 0

Present $1 /$ absent 0.
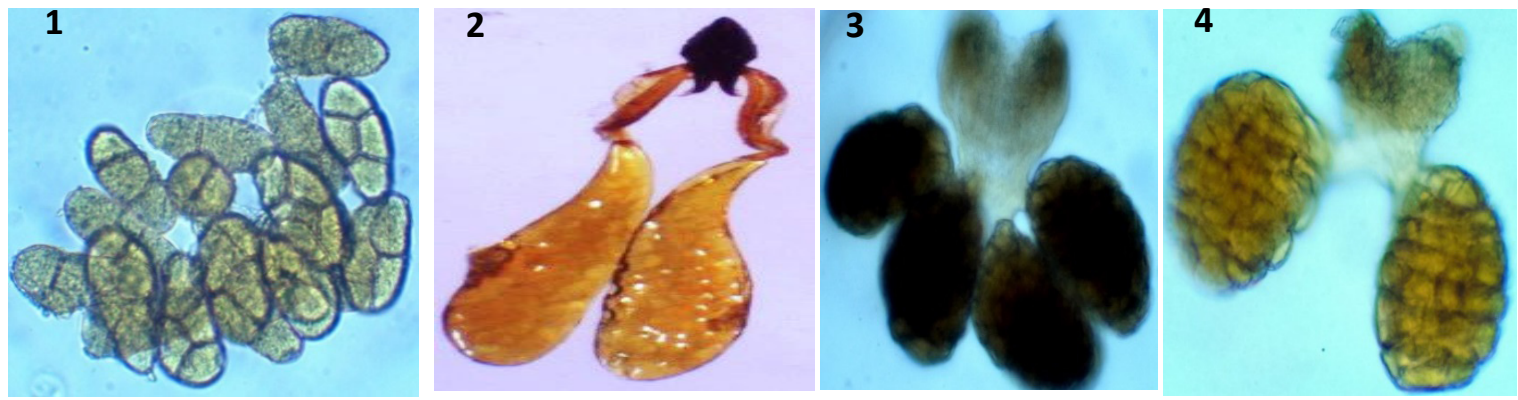

Fig. 1-4. (1) Periploca laevigata (tetrads of pollen grains). (2 )Asclepias verticillata (pendulous twin pollinia). (3) Secamone frutescens (tetrad of erect pollinia). (4) Secamone retusa (tetrad of erect pollinia; a polliniumfrom each pair is removed to reveal the absence of a common thin membrane enveloping each individual pollinium).

\section{Discussion}

The present results seem to indicate that the Asclepiadaceae comprises only two major groups: The first includes only the Asclepiadoideae, while the second combines the Secamonoideae and Periplocoideae. This notion is different from the views expressed by Endress \& Bryuns (2000) that the Secamonoideae falls somewhere between the Asclepiadoideae and Periplocoideae. The latter subfamily and the Secamonoideae seem much closer to each other than either of them to Asclepiadoideae (Fig. 5).

In order to achieve the highest degree of similarity between the dendrogram in Fig. 5 and Schumann's (1895) classification, a stopping level of distance in the dendrogram was found at the 17 low-level groups. The three subfamilies Asclepiadoideae, Periplocoideae and Secamonoideae comprise groups 1-12, 13-14 and $15-17$, respectively. Out of the seven tribes in Schumann's (1895) classification represented in the present study, the SecamonoideaeSecamoneae is theonly tribe to emerge intact (Table 2), thus indicating that there is plenty of room for improvement at the tribal level in that classification. Representatives of other tribes suffered various degrees of fragmentation and are dispersed between the low-level groups as follows: The Glossonematinae in groups 1, 2 and 9; the Cynanchinae in groups 2, 7,8 and 9; the Marsdeniinae in groups 3, 5 and 7; the Ceropegiinae in groups 4 and 12; the Asclepiadinae in groups 5, 6, 10 and 11; the Periploceae in groups 5,13 and 14. 


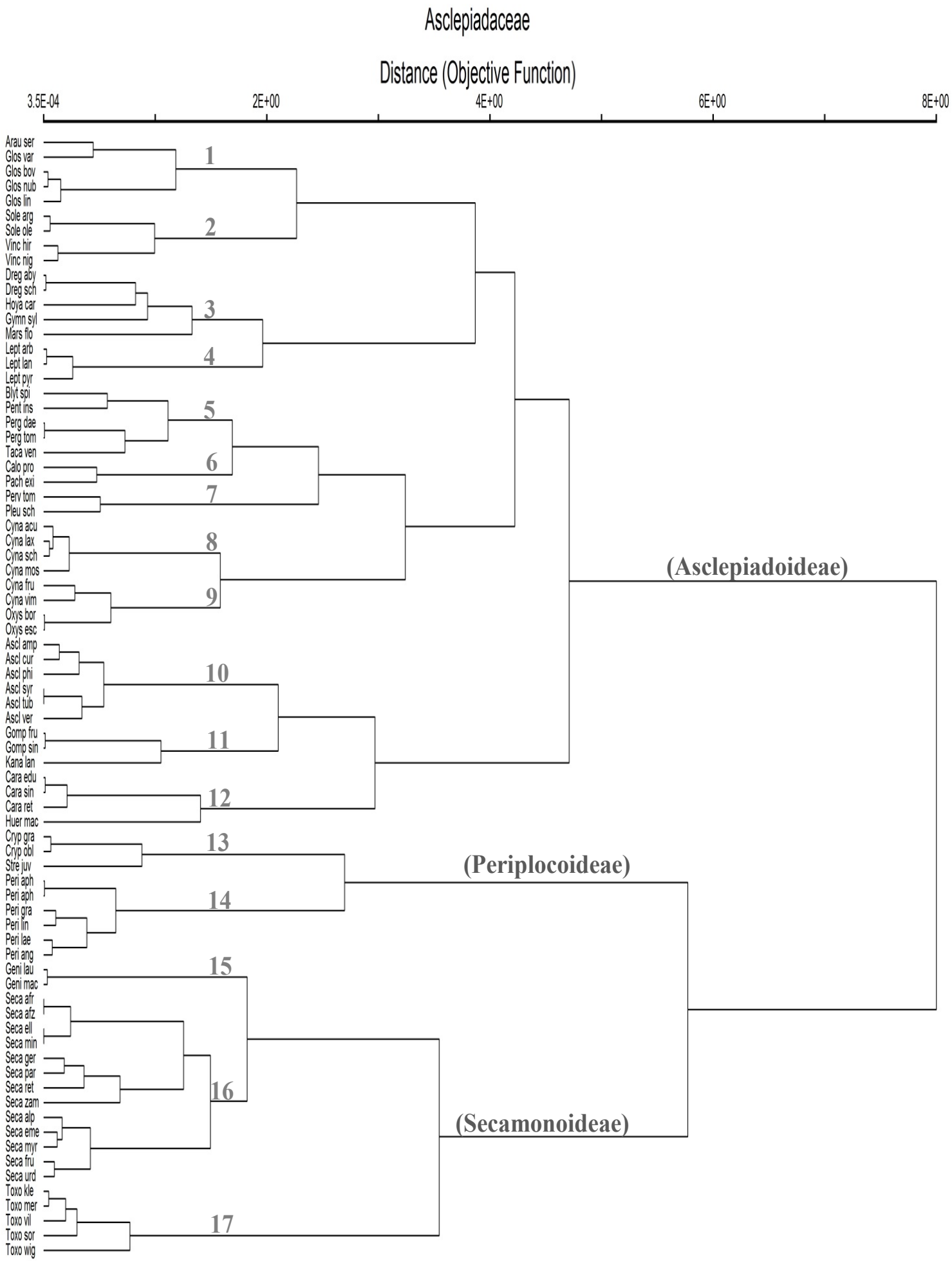

Fig. 5. Dendrogram illustrating the hierarchical classification of 76 taxa representing 31 genera of the Asclepiadaceae s. $l$. based on the 58 characters listed in Table 1 and analysed under the Jaccard distance measure and Ward'sclustering method. Abbreviations of species names and their full version are provided in the Appendix. 
TABLE 2. Comparison between the major and low-level groups in Fig. 5 and their counterparts in Schumann's (1895) classification of the Asclepiadaceae s.l. The number of species representing each genus is given in parenthesis.

\begin{tabular}{|c|c|c|}
\hline Genera & Subfamilies-groups 1-17 & $\begin{array}{l}\text { Schumann (1895) } \\
\text { Subfamilies-tribes-subtribes }\end{array}$ \\
\hline $\operatorname{Araujia}(1)$ & Asclepiadoideae-1 & Cynanchoideae -Asclepiadeae-Glossonimatinae \\
\hline Glossonema (4) & Asclepiadoideae-1 & Cynanchoideae -Asclepiadeae-Glossonimatinae \\
\hline Solenostemma(2) & Asclepiadoideae-2 & Cynanchoideae -Asclepiadeae-Glossonimatinae \\
\hline Vincetoxicum(2) & Asclepiadoideae-2 & Cynanchoideae -Asclepiadeae-Cynanchinae \\
\hline Dregea (2) & Asclepiadoideae-3 & Cynanchoideae-Tylophoreae-Marsdeniinae \\
\hline Hoya (1) & Asclepiadoideae-3 & Cynanchoideae-Tylophoreae-Marsdeniinae \\
\hline Gymnema (1) & Asclepiadoideae-3 & Cynanchoideae-Tylophoreae-Marsdeniinae \\
\hline Marsdenia (1) & Asclepiadoideae-3 & Cynanchoideae-Tylophoreae-Marsdeniinae \\
\hline Leptadenia (3) & Asclepiadoideae-4 & Cynanchoideae-Tylophoreae-Ceropegiinae \\
\hline Blyttia (1) & Asclepiadoideae-5 & Cynanchoideae -Asclepiadeae-Cynanchinae \\
\hline Pentarrhinum (1) & Asclepiadoideae-5 & Cynanchoideae -Asclepiadeae- Asclepiadinae \\
\hline Pergularia (2) & Asclepiadoideae-5 & Cynanchoideae-Tylophoreae-Marsdeniinae \\
\hline Tacazzia (1) & Asclepiadoideae-5 & Periplocoideae-Periploceae \\
\hline Calotropis (1) & Asclepiadoideae-6 & Cynanchoideae -Asclepiadeae-Asclepiadinae \\
\hline Pachycarpus (1) & Asclepiadoideae-6 & Cynanchoideae -Asclepiadeae-Asclepiadinae \\
\hline Pervillaea (1) & Asclepiadoideae-7 & Cynanchoideae-Tylophoreae-Marsdeniinae \\
\hline Pleurostelma $(1)$ & Asclepiadoideae-7 & Cynanchoideae -Asclepiadeae-Cynanchinae \\
\hline Cynanchum (4) & Asclepiadoideae-8 & Cynanchoideae -Asclepiadeae-Cynanchinae \\
\hline Cynanchum (2) & Asclepiadoideae-9 & Cynanchoideae -Asclepiadeae-Cynanchinae \\
\hline Oxystelma(2) & Asclepiadoideae-9 & Cynanchoideae -Asclepiadeae-Glossonimatinae \\
\hline Asclepias (6) & Asclepiadoideae-10 & Cynanchoideae -Asclepiadeae-Asclepiadinae \\
\hline Gomphocarpus (2) & Asclepiadoideae-11 & Cynanchoideae -Asclepiadeae-Asclepiadinae \\
\hline Kanahia $(1)$ & Asclepiadoideae-11 & Cynanchoideae -Asclepiadeae-Asclepiadinae \\
\hline Caralluma (3) & Asclepiadoideae 12 & Cynanchoideae-Tylophoreae-Ceropegiinae \\
\hline Huernia(1) & Asclepiadoideae-12 & Cynanchoideae-Tylophoreae-Ceropegiinae \\
\hline Cryptostegia (1) & Periplocoideae-13 & Periplocoideae-Periploceae \\
\hline Cryptolepis (1) & Periplocoideae-13 & Periplocoideae-Periploceae \\
\hline Streptocaulon(1) & Periplocoideae-13 & Periplocoideae-Periploceae \\
\hline Periploca (6) & Periplocoideae-14 & Periplocoideae-Periploceae \\
\hline Genianthus (2) & Secamonoideae-15 & Cynanchoideae-Secamoneae \\
\hline Secamone (13) & Secamonoideae-16 & Cynanchoideae-Secamoneae \\
\hline Toxocarpus (5) & Secamonoideae-17 & Cynanchoideae-Secamoneae \\
\hline
\end{tabular}

Unlike Schumann's tribes, the generic concept in the Asclepiadaceae is remarkably robust. Of the 14 genera represented in the present analysis by two or more species each, 13 have emerged intact. The only genus to be divided between two of the low-level groups is Cynanchum, with 4 species in group 8 and 2 species in the closely related group 9. Furthermore, six genera are so distinct that each of them forms its own separate group. These genera are: Leptadenia (group 4), Asclepias (group 10), Periploca (group 14), Genianthus (group 15), Secamone (group 16), and Toxocarpus (group 17).

Tacazzia is a member of Schumann's Periplocoideae-Periploceaebut seems better 
placed in group 5 together with Blyttia (unknown in Schumann's scheme), Pentarrhinum (of the Cynanchoideae-Asclepiadeae-Asclepiadinae), and Pergularia (of the CynanchoideaeTylophoreae- Marsdeniinae).

\section{Conclusion}

Owing to the relatively small sample of genera and species, the arrangement of the 31 genera of Asclepiadaceae provided in Fig. 5 and Table 2 is by no means intended as a formal classification of the family. Rather, it is meant to show that dependence on a limited number of characters from a single source (pollen, flowers, or fruits), to recognize major groupings within a relatively large family as the Asclepiadaceae can lead to major misplacements and clearly heterogeneous infra-familial taxa. The groupings recognized in the present study, therefore, have the advantage of being based on the largest number of characters which have as yet been studied comparatively in all parts of the plants.

Acknowledgements: We wish to thank Prof. Dr. Abbas El-Ghamri (Department of Botany and Microbiology, Faculty of Science in Cairo, AlAzhar University) for laboratory and library facilities and useful suggestions throughout this study.

\section{References}

APG IV (2016) An update of the Angiosperm Phylogeny Group classification for the orders and families of flowering plants. Botanical Journal of the Linnean Society, 181, 1-20.

Bentham, G. and Hooker, J.D. (1876) "Asclepiadeae. Genera Plantarum", Vol. 2. J. Cramer, Weinheim, pp. 728-785.

Brown, R. (1811) On the Asclepiadeae, a natural order of plants separated from the Apocineae of Jussieu. Preprint of Memoirs of the Wernerian Natural History Society, 1, 12-78.

Dave, Y. and Kuriashen, P.M. (1991) Comparative anatomical characters of Periplocaceae follicles and their taxonomic significance. Feddes Repertorium, 102, 63-68.

Decaisne, J. (1844) "Asclepiadaceae, in De Candolle's Prodromus Systematis Naturalis Regni
Vegetabilis", Vol. 8, pp. 490-665. Fortin, Masson \& Co., Paris.

El-Gazzar, A. and Hamza, M.K. (1973) Morphology of the twin pollinia of Asclepiadaceae. Pollen et Spores, 15(3-4), 459-470.

El-Gazzar, A., Hamza, M.K. and Badawi, A.A (1974) Pollen morphology and taxonomy of Asclepiadaceae. Pollen et Spores, 16, 227-238.

Endress, M.E. (2001) Apocynaceae and Asclepiadaceae: United they stand. Haseltonia, 8, 2-9.

Endress, M.E. and Bruyns, P.V. (2000) A revised classification of the Apocynaceae s.l. Botanical Review, 66(1), 1-56.

Endress, M.E., Liede-Schumann, S. and Meve, U. (2014) An updated classification for Apocynaceae. Phytotaxa, 159(3), 175-194.

Franks, J.W. and Watson, L. (1963) The pollen morphology of some critical Ericales. Pollen et Spores, 5, 51-68.

Holmgren, P.K., Holmgren, N.H. and Barnett, L.C. (1990) "Index Herbariorum. Part 1. The Herbaria of the World. Regnum Vegetabile", Vol. 120. pp. 693.

Jussieu, A.de. (1789) "Genera Plantarum. Viduam Herissant", Paris, pp 526.

Khanum, R., Surveswaram, S., Meve, U. and LiedeSchumann, S. (2016) Cynanchum (Apocynaceae: Asclepiadoideae): A pantropical asclepiadoid genus revisited. Taxon, 65(3), 467-486.

Kunze, H. (1996) Morphology of the stamen in the Asclepiadaceae and its systematic relevance. Botanischer Jahrbücher für Systematik, Pflanzengeschichte und Pflanzengeographie, 118, 547-579.

Liede, S. and Albers, F. (1994) Tribal disposition of genera in the Asclepiadaceae. Taxon, 43, 201-231.

Liede-Schumann, S., Kong, H., Meve, U. and Thiv, M. (2012) Vincetoxicum and Tylophora (ApocynaceaeAsclepiadoideae-Asclepiadeae) two sides of the same medal: Independent shifts from tropical to temperate habitats. Taxon, 61(4), 803-825. 
Liede-Schumann, S., Nikolaus, M., Silva, U.C.S.S., Rapini, A., Mangelsdorff, R.D. and Meve, U. (2014) Phylogenetics and biogeography of the genus Metastelma (Apocynaceae-AsclepiadoideaeAsclepiadeae-Metastelmatinae). Systematic Botany, 39(2), 594-612.

Livshultz, T., Middleton, D.J., Endress, M.E. and Williams, J.K. (2007) Phylogeny of Apocynoideae and the APSA clade (Apocynaceae s.l.). Annales of the Missouri Botanical Garden, 94(2), 324-359.

McCune, B. (1997) PC-ORD version 5, for windows. Specification.[https://www.pcord.com/pcordwin. $\mathrm{htm}]$

Meve, U. and Liede-Schumann, S. (2004) Generic delimitations in tuberous Periplocoideae (Apocynaceae) from Africa and Madagascar. Annalls of Botany, 93(4), 407-414.

Meve, U. and Liede-Schuman, S. (2012) Taxonomic dissolution of Sarcostemma (ApocynaceaeAsclepiadoideae). Kew Bulletin, 67, 751-759.

Meve, U., Heiduk, A. and Liede-Schumann, S. (2017) Origin and early evolution of Ceropegieae (Apocynaceae-Asclepiadoideae). Systematics and Biodiversity, 15(2), 143-155.

Nilsson, S., Endress, M.E. and Grafström, E. (1993) On the relationship of the Apocynaceae and Periplocaceae. Grana supplement, 2, 3-20.

Schill, R. and Jäkel, U. (1978) Beitrag zur Kenntnis der Asclepiadaceen-pollinarien. Tropische und Subtropische Pflanzenwelt, 22,7-22.

Schlechter, R. (1905) Periplocaceae. In: "Nachträge zur Flora des Deutschen Schutzgebiete in der Südsee", Schumann, K., Lauterbach, K. (Ed.), pp. 351-353. Borntraeger, Leipzig.

Schlechter, R. (1924) Periplocaceae. Notizblatt des Botanischen Gartens und Museums zu BerlinDahlem, 9, 23-40.

Schumann, K. (1895) Asclepiadaceae. A. Engler and K. Prantl's Die natürlichen Pflanzenfamilien, 4(2), 189-306.
Sennblad, B. and Bremer, B. (1996) The familial and subfamilial relationships of Apocynaceae and Asclepiadaceae evaluated with $r b c \mathrm{~L}$ data. Plant Systematics and Evolution, 202, 153-175.

Sennblad, B. and Bremer, B. (2002) Classification of Apocynaceae s.l. according to a new approach combining Linnaean and phylogenetic taxonomy. Systematic Biology, 51(3), 389-409.

Soares e Silva, U.C., Rapini, A., Liede-Schumann, S., Ribeiro, P.L. and Van den Berg, C. (2012) Taxonomic considerations on Metastelmatinae (Apocynaceae) based on plastid and nuclear DNA. Systematic Botany, 37(3), 795-806.

Sreenath, K.P., Ramakrishna, T.M. and Babu, T.P. (2012) Perspective on pollinial apparatus of Asclepiadaceae sensu lato. Global Journal of BioScience \& Biotechnology, 1(1), 45-53.

Surveswaram, S., Sun, M., Grimm, G.W. and LiedeSchumann, S. (2014) On the systematic position of some Asian enigmatic genera of Asclepiadoideae (Apocynaceae). Botanical Journal of the Linnean Society, 174, 601-619.

Swarupanandan, K.J.K., Mangaly, T.K., Sonny, K., Kishorekumar, K. and Chand Basha, S. (1996) The subfamilial and tribal classification of the family Asclepiadaceae. Botanical Journal of the Linnean Society, 120, 327-369.

Verhoeven, R.L. and Venter, H.J.T. (1998) Pollinium structure in Periplocoideae (Apocynaceae). Grana, 37, 1-14.

Watson, L. and Dallwitz, M.J. (1992 onwards) The families of flowering plants. descriptions, illustrations, identification, and information retrieval. Version: $20^{\text {th }}$ June 2017. delta-intkey. com/angio'.

(Received 27/ $2 / 2018$ accepted 18 / 4 /2018) 


\section{التصنيف العددي للفصيلة العشارية بمعناها الواسع}

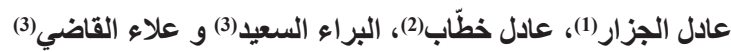

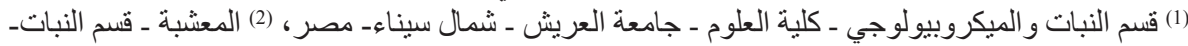

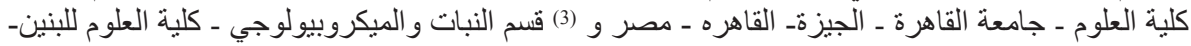

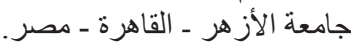

تم تسجيل 58 صفة بطريقة مقارنة لعينة من 76 نوع تنتمي إلى 31 جنس من نباتات الفصيلة العشارية بمعناها

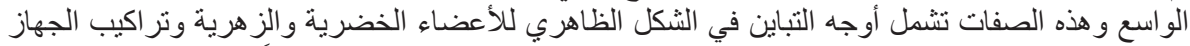

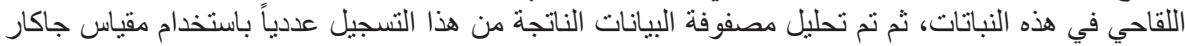

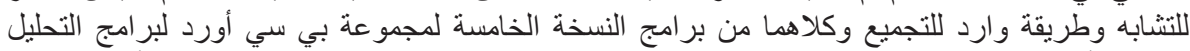

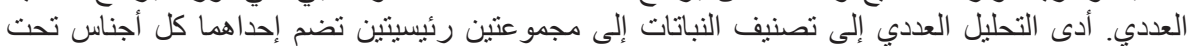

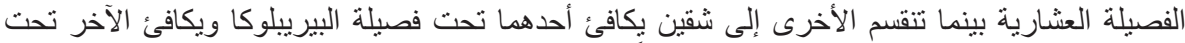

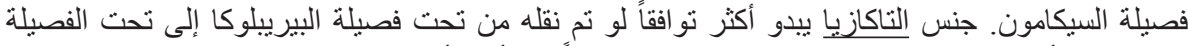

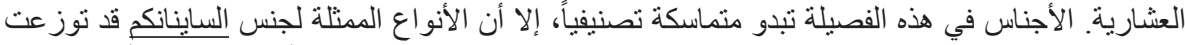

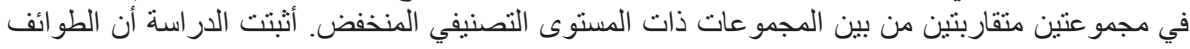

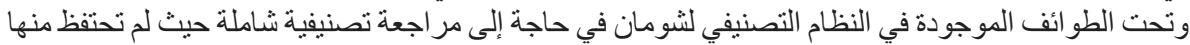
بتماسكها إلا تحت طائفة السيكامون في تحت فصيلة السيكامون. 